University of Nebraska - Lincoln

DigitalCommons@University of Nebraska - Lincoln

2006

Prediction Failure of a Wolf Landscape Model

L. David Mech

USGS Northern Prairie Wildlife Research Center, david_mech@usgs.gov

Follow this and additional works at: https://digitalcommons.unl.edu/usgsnpwrc

Part of the Other International and Area Studies Commons

Mech, L. David, "Prediction Failure of a Wolf Landscape Model" (2006). USGS Northern Prairie Wildlife Research Center. 94.

https://digitalcommons.unl.edu/usgsnpwrc/94

This Article is brought to you for free and open access by the US Geological Survey at DigitalCommons@University of Nebraska - Lincoln. It has been accepted for inclusion in USGS Northern Prairie Wildlife Research Center by an authorized administrator of DigitalCommons@University of Nebraska - Lincoln. 


\title{
Prediction Failure of a Wolf Landscape Model
}

\author{
L. DAVID MECH, ${ }^{\mathbf{1 , 2}}$ United States Geological Survey, Northern Prairie Wildlife Research Center, Jamestown, ND 58401, USA
}

\begin{abstract}
I compared 101 wolf (Canis lupus) pack territories formed in Wisconsin during 1993-2004 to the logistic regression predictive model of Mladenoff et al. $(1995,1997,1999)$. Of these, $60 \%$ were located in putative habitat suitabilities $<50 \%$, including $22 \%$ in suitabilities of $0-9 \%$. About a third of the area with putative suitabilities $>50 \%$ remained unoccupied by known packs after 24 years of recolonization. This model was a poor predictor of wolf re-colonizing locations in Wisconsin, apparently because it failed to consider the adaptability of wolves. Such models should be used cautiously in wolf-management or restoration plans. (WILDLIFE SOCIETY BULLETIN 34(3):874-877; 2006)
\end{abstract}

\section{Key words}

Canis lupus, landscape, model, recolonization, Wisconsin, wolf.

Predicting areas large carnivores might colonize upon natural recovery or reintroduction would be useful to resource managers. There have been 4 attempts to develop spatial models to predict such areas for gray wolves (Canis lupus; Mladenoff et al. 1995, 1997, 1999, Harrison and Chapin 1997, Corsi et al. 1999, Glenz et al. 2001).

Mladenoff et al. (1995, 1997, 1999) developed a logistic regression model based on landscape data and previous findings early during the wolf recovery (1979-1992) in Wisconsin, USA. The model suggested wolves tended to colonize and survive in areas with road densities $\leq 0.6 \mathrm{~km} / \mathrm{km}^{2}$ (Thiel 1985). The model derived putative wolf-habitat-suitability probabilities ranging from $0-100 \%$. This model was used to predict where wolves might colonize Wisconsin, Michigan, and Minnesota, USA (Mladenoff et al. 1995, 1997, 1999), and was applied similarly to the northeastern United States (Mladenoff and Sickley 1998).

Sufficient time has now elapsed to evaluate the Mladenoff et al. $(1995,1997,1999)$ model with the current distribution of wolf territories in Wisconsin. Herein, I make such a comparison.

\section{Methods}

I used data on wolf-pack-territory locations gathered by the Wisconsin Department of Natural Resources from 1993-2004 (Fig. 1) to compare their map locations to the wolf habitatsuitability-probability map of Mladenoff et al. (1999:39; Fig. 2).

I enlarged the habitat-suitability map to the same size and scale as the pack-territory map. I then overlaid a transparent acetate copy of the pack-territory map on the habitat-probability map and directly read the probability for each territory. Where a territory boundary enclosed areas of more than one probability, I scored the probability encompassing the greatest portion of the territory for that territory. If a territory enclosed areas of several probabilities, I used an integrated probability. Because some of the territory boundaries were based on estimates rather than on radiotracking locations (Wydeven and Wiedenhoeft 2004) and, thus, might not have been accurate, I independently used only the 54 territories based on radiotelemetry data.

\footnotetext{
1 E-mail: david_mech@usgs.gov

2 Mailing address: The Raptor Center, University of Minnesota, St. Paul, MN 55108, USA
}

\section{Results}

I compared 101 wolf-pack territories discovered in Wisconsin between 1993-2004 (Fig. 1) with the Mladenoff et al. (1999) habitat-suitability map. Of these, $60 \%$ were located in areas of putative suitabilities $<50 \%$, including $22 \%$ which were in areas of $0-9 \%$ suitability (Table 1 ). When I compared only the 54 territories based on radiotracking, I obtained similar results (Table 1). Additionally, more than a third of the Wisconsin area with putative suitability $>50 \%$ (Mladenoff et al. 1999:39) remained unoccupied by known packs of wolves during the 24 years of recolonization (cf. Mladenoff et al. 1999 and Fig. 1), even though the areas were well within dispersal distances for wolves (Wydeven et al. 1995) and wolves repopulated many areas of putative low probability (Table 1).

\section{Discussion}

The Mladenoff et al. (1995) model was derived to predict areas wolves had the greatest chance of re-colonizing. It was based on characteristics of areas inhabited by 14 wolf packs in Wisconsin between 1979-1992 and tested on 13 packs that colonized Wisconsin between 1993-1996 (Mladenoff et al. 1999). The model was then applied to both the northeastern United States to assess potential wolf habitat there (Mladenoff and Sickley 1998) and in the Wisconsin Wolf Management Plan (Wisconsin Department of Natural Resources 1999) to assess potential wolf habitat.

My results, based on 101 packs colonizing Wisconsin between 1993-2004, indicate the logistic regression model (Mladenoff et al. 1995, 1997, 1999) failed to predict extensive areas, both where wolf packs would colonize and where they would not. Because the model is supposed to be predictive, it was anticipated most wolves would colonize the areas of highest probability. Instead $60 \%$ of the packs colonized areas of $<50 \%$ probability, including $22 \%$ in areas of the lowest probability. In addition, about a third of the available area of high probability was not known to be colonized. Wisconsin provides an ideal area in which to assess the model because it was originally derived from the Wisconsin wolf population. If it does not work there, there might be little reason to believe it would work elsewhere.

How could the model have failed to predict where Wisconsin wolves would re-colonize just a few years after it was devised? The 


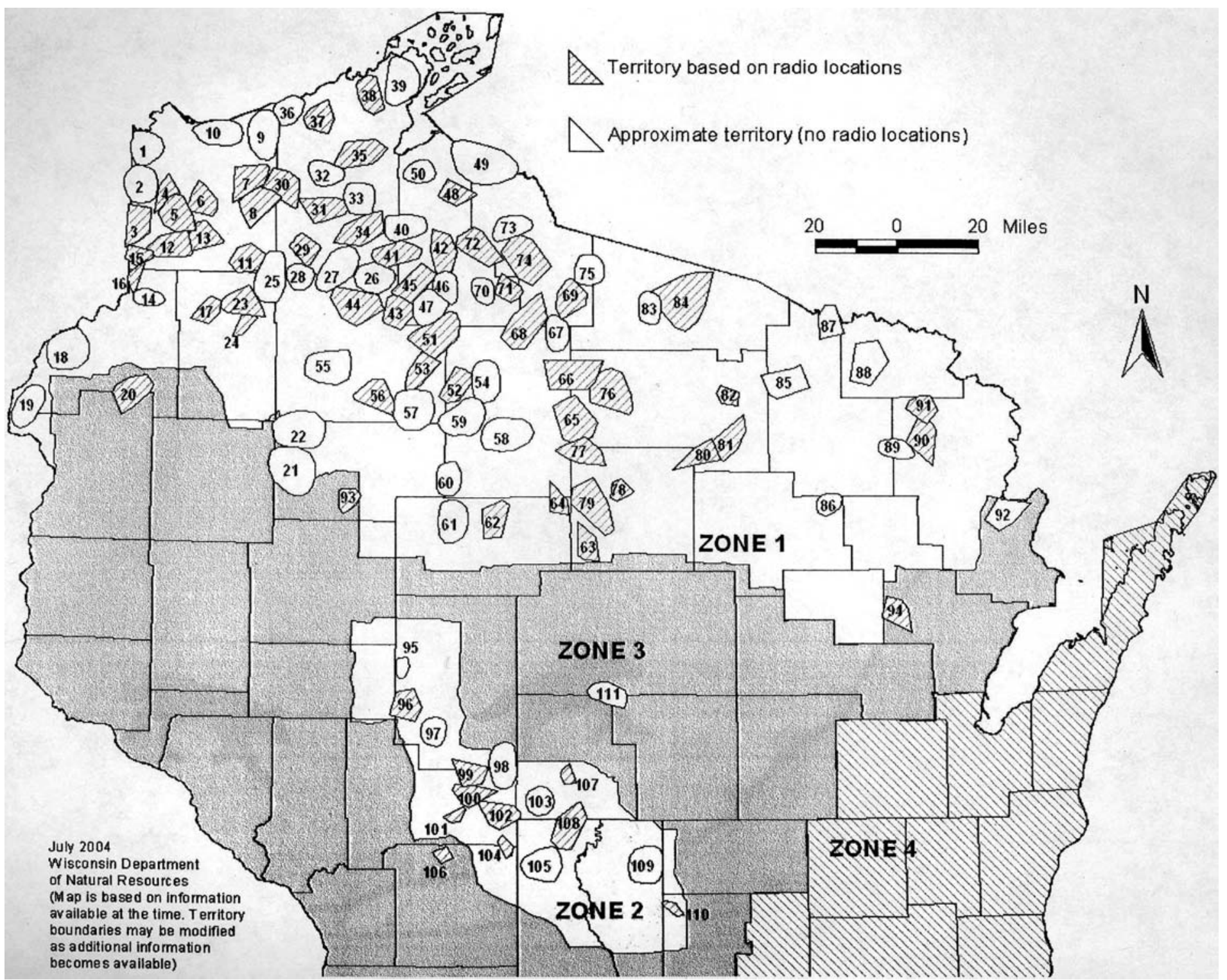

Figure 1. Wolf-pack territories formed in Wisconsin, USA, 1997-2004 (Wydeven and Wiedenhoeft 2004).

model clearly was descriptive, rather than predictive, merely characterizing areas where wolves were living during 1979-1992, not necessarily where they would live. The areas first colonized tended to be wild areas with low road densities (Thiel 1985) because 1) wolves living elsewhere were killed by humans, both illegally and accidentally (Wydeven et al. 1995), 2) the original colonizers came from Minnesota (Mech et al. 1995) where they had lived primarily in wild lands, and 3) wolves tend to colonize areas by proliferation from core areas (Fritts and Mech 1981, Ream et al. 1991, Wydeven et al. 1995). Since core recolonization areas tended to be wild lands, then early proliferation from those core areas tended to be in similar areas.

It is clear that wolves do not require wilderness (Boitani 1982, Mech 1995). Originally they inhabited almost every kind of habitat in the northern hemisphere (Young and Goldman 1944). The reason wolves remaining in the contiguous 48 states after a major extermination campaign inhabited only wild lands is because that is the only place where they avoided human persecution. In effect, humans relegated wolves to wild lands (Mech 1995).

In many parts of Europe, however, wolves frequent villages at night (Boitani 1982), roam through cities to scavenge at garbage landfills (Promberger et al. 1997) and den in wheat fields (Vila et al. 1993). Signs of similar behavior have long been noted in the United States as well (Mech 1995). In Minnesota wolves have been colonizing areas where road densities exceed the $0.6 \mathrm{~km} / \mathrm{km}^{2}$ that Thiel (1985) found characterized areas inhabited by remnant wolf populations and early colonizers (Mech 1989, Fritts et al. 1992, Berg and Benson 1999, Merrill 2000). They have even denned and raised pups in areas of high human disturbance (Thiel et al. 1998).

Thus, wolf recolonization of areas of putative low suitability in Wisconsin (Mladenoff et al. 1995, 1997, 1999) is not surprising. That recolonization does, however, reinforce the concerns of the Eastern Timber Wolf Recovery Plan (U.S. Fish and Wildlife Service 1992) and of Mech $(1995,1998,2001)$ that re-colonizing 


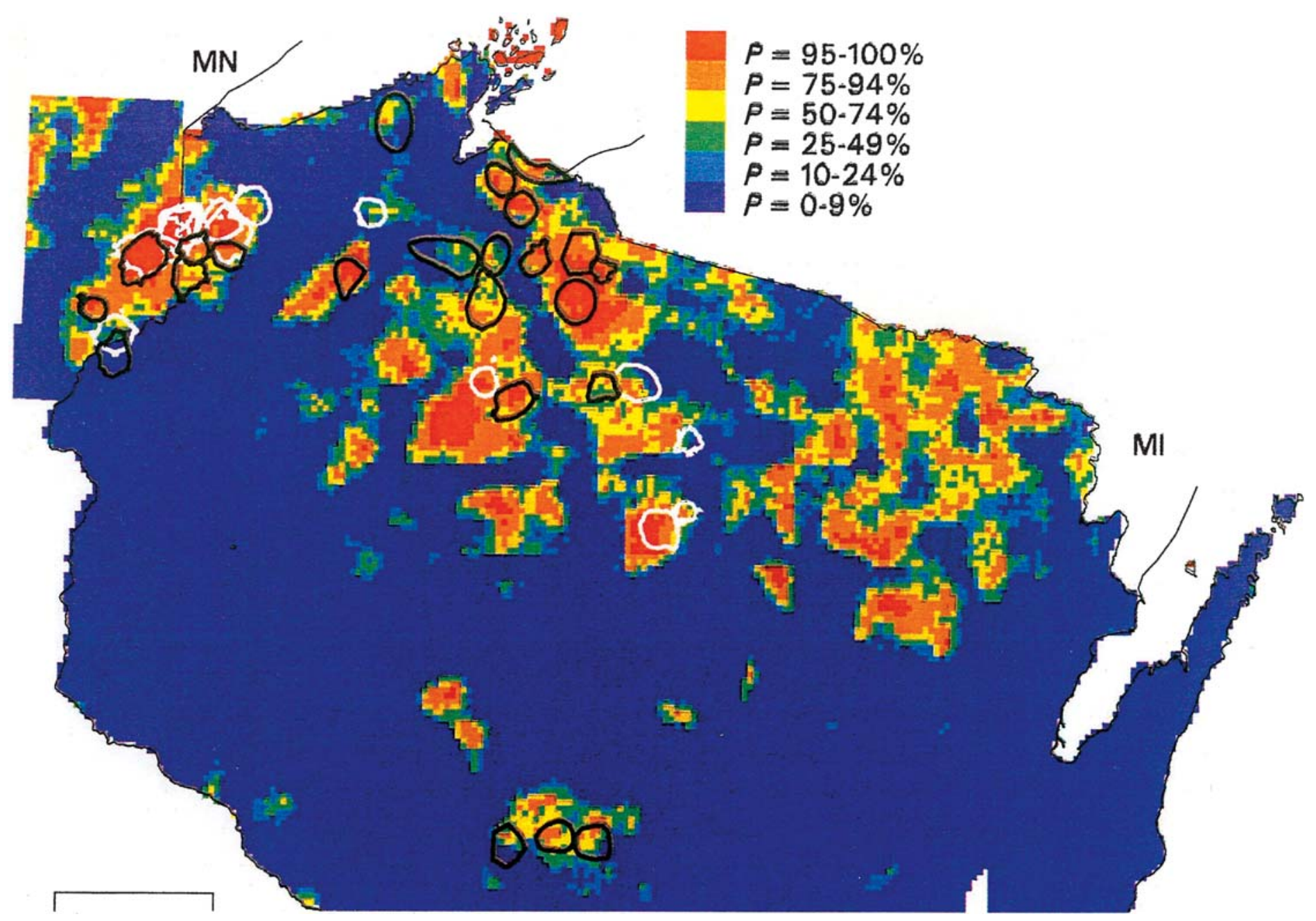

Figure 2. Map of putative wolf-favorability classes in northern Wisconsin, USA, including wolf-pack territories used in creating the model (white boundaries) and territories originating from 1993 to 1996 (Mladenoff et al. 1999).

wolves could result in considerable conflict with humans if not restricted by management to wild lands.

These findings also caution that 1 ) other models of putative wolf habitat suitability that fail to consider the adaptability of wolves and attempt to draw inferences from areas of artificially induced wolf-range restrictions may also be similarly flawed, and 2) wolfrange projections in wolf management plans, such as those in Michigan (Michigan Department of Natural Resources 1997) and

Table 1. Distribution of 101 new Wisconsin, USA, wolf-pack territories, 19972004 (Wydeven and Wiedenhoeft 2004), in relation to putative habitat-suitability classes as modeled by Mladenoff et al. (1995, 1997, 1999).

\begin{tabular}{crrrrr}
\hline & \multicolumn{4}{c}{ New territories } \\
\cline { 2 - 3 } $\begin{array}{c}\text { Putative suitability } \\
\text { probability (\%) }\end{array}$ & \multicolumn{2}{c}{ All } & & \multicolumn{2}{c}{ Radiotelemetry-based only } \\
\cline { 2 - 3 } \cline { 5 - 6 } \cline { 5 - 6 } & No. & & No. & \% \\
\hline $95-100$ & 9 & 9 & 7 & 13 \\
$75-94$ & 18 & 18 & & 9 & 17 \\
$50-74$ & 14 & 14 & & 9 & 17 \\
$25-49$ & 20 & 20 & & 6 & 11 \\
$10-24$ & 18 & 18 & & 9 & 17 \\
$0-9$ & 22 & 22 & & 14 & 26 \\
\hline
\end{tabular}

Wisconsin (Wisconsin Department of Natural Resources 1999) that are based on unrealistic assumptions of the Mladenoff et al. (1995, 1997, 1999) model, should be reconsidered.

\section{Acknowledgments}

This study was supported by the Biological Resources Division, United States Geological Survey. I also appreciate the critiques of the manuscript by the following who offered helpful suggestions for improvement: D. R. MacNulty, M. E. Nelson, and W. E. Newton.

\section{Literature Cited}

Berg, W., and S. Benson. 1999. Updated wolf population estimate for Minnesota, 1997-1998. Minnesota Department of Natural Resources Report, Grand Rapids, USA.

Boitani, L. 1982. Wolf management in intensively used areas of Italy. Pages 158-172 in F. H. Harrington and P. C. Paquet, editors. Wolves of the world. Noyes, Park Ridge, New Jersey, USA.

Corsi, F., E. Pupre, and L. Boitani. 1999. A large-scale model of wolf distribution in Italy for conservation planning. Conservation Biology 13:150 159.

Fritts, S. H., and L. D. Mech. 1981. Dynamics, movements, and feeding ecology of a newly protected wolf population in northwestern Minnesota. Wildlife Monographs 80. 
Fritts, S. H., W. J. Paul, L. D. Mech, and D. P. Scott. 1992. Trends and management of wolf-livestock conflicts in Minnesota. U.S. Department of the Interior, Fish and Wildlife Service Resource Publication 181, Washington, D.C., USA.

Glenz, C., A. Massolo, D. Kuonen, and R. Schlaepfer. 2001. A wolf habitat suitability prediction study in Valais (Switzerland). Landscape and Urban Planning 55:55-65.

Harrison, D. J., and T. G. Chapin. 1997. An assessment of potential habitat for eastern timber wolves in the northeastern United States and connectivity with occupied habitat in southeastern Canada. Wildlife Conservation Society, Working Paper 7, New York, New York, USA.

Mech, L. D. 1989. Wolf population survival in an area of high road density. American Midland Naturalist 121:387-389.

Mech, L. D. 1995. The challenge and opportunity of recovering wolf populations. Conservation Biology 9:270-278.

Mech, L. D. 1998. Estimated costs of maintaining a recovered wolf population in agricultural regions of Minnesota. Wildlife Society Bulletin 26:817-822.

Mech, L. D. 2001. Managing Minnesota's recovered wolves. Wildlife Society Bulletin 29:70-77.

Mech, L. D., S. H. Fritts, and D. Wagner. 1995. Minnesota wolf dispersal to Wisconsin and Michigan. American Midland Naturalist 133:368-370.

Merrill, S. B. 2000. Road densities and wolf, Canis lupus, habitat suitability: an exception. Canadian Field Naturalist 114:312-313.

Michigan Department of Natural Resources. 1997. Michigan gray wolf recovery and management plan. Michigan Department of Natural Resources, Lansing, USA.

Mladenoff, D. J., R. G. Haight, T. A. Sickley, and A. P. Wydeven. 1997. Causes and implications of species restoration in altered ecosystems. Bioscience 47:21-31.

Mladenoff, D. J., and T. A. Sickley. 1998. Assessing potential grey wolf restoration in the northeastern United States: a spatial prediction of favorable habitat and potential population levels. Journal of Wildlife Management 62:110.

Mladenoff, D. J., T. A. Sickley, R. G. Haight, and A. P. Wydeven. 1995. A regional landscape analysis and prediction of favorable grey wolf habitat in the northern Great Lakes region. Conservation Biology 9:279-294.

Mladenoff, D. J., T. A. Sickley, and A. D. Wydeven. 1999. Predicting gray wolf landscape recolonization: logistic regression models vs. new field data. Ecological Applications 9:37-44.

Promberger, C., O. Ionescu, L. Petre, C. Roschak, P. Surth, B. Furpa, L. Todicescu, A. Sandor, M. Minca, T. Stan, H. Homm, G. Predoiu, and M. Scurtu. 1997. Carpathian large carnivore project. Annual report 1996/97. Munich Wildlife Society, Ettal, Germany.

Ream, R. R., M. W. Fairchild, D. K. Boyd, and D. H. Pletscher. 1991. Population dynamics and home range changes in a colonizing wolf population. Pages 349-366 in M. Boyce and R. Keiter, editors. The greater Yellowstone ecosystem: redefining America's wilderness heritage. Yale University, New Haven, Connecticut, USA, and London, United Kingdom.

Thiel, R. P. 1985. Relationship between road densities and wolf habitat suitability in Wisconsin. American Midland Naturalist 113:404-407.

Thiel, R. P., S. B. Merrill, and L. D. Mech. 1998. Tolerance by denning wolves, Canis lupus, to human disturbance. Canadian Field Naturalist 112:340-342.

U.S. Fish and Wildlife Service. 1992. Recovery plan for the eastern timber wolf, revised edition. United States Fish and Wildlife Service, Minneapolis and St. Paul, Minnesota, USA.

Vila, C., J. Castroviejo, and V. Urios. 1993. The Iberian wolf in Spain. Pages 105-109 in C. Promberger and W. Schroder, editors. Wolves in Europecurrent status and perspectives. Munich Wildlife Society, Ettal, Germany.

Wisconsin Department of Natural Resouces. 1999. Wisconsin wolf management plan, 27 October 1999. Wisconsin Department of Natural Resources, Madison, USA.

Wydeven, A. P., R. N. Schultz, and R. P. Thiel. 1995. Monitoring of a gray wolf, Canis lupus, population in Wisconsin, 1979-1991. Pages 147-156 in L. N. Carbyn, S. H. Fritts, and D. R. Seip, editors. Ecology and conservation of wolves in a changing world. Canadian Circumpolar Institute, Occasional Publication 35, Edmonton, Alberta, Canada.
Wydeven, A., and P. J. E. Wiedenhoeft. 2004. Status of the timber wolf in Wisconsin. Wisconsin Endangered Resources, performance report 1 July 2003 through 30 June 2004. Wisconsin Department of Natural Resources, Park Falls, USA.

Young, S. P., and E. A. Goldman. 1944. The wolves of North America. Wildlife Management Institute, Washington, D.C., USA.

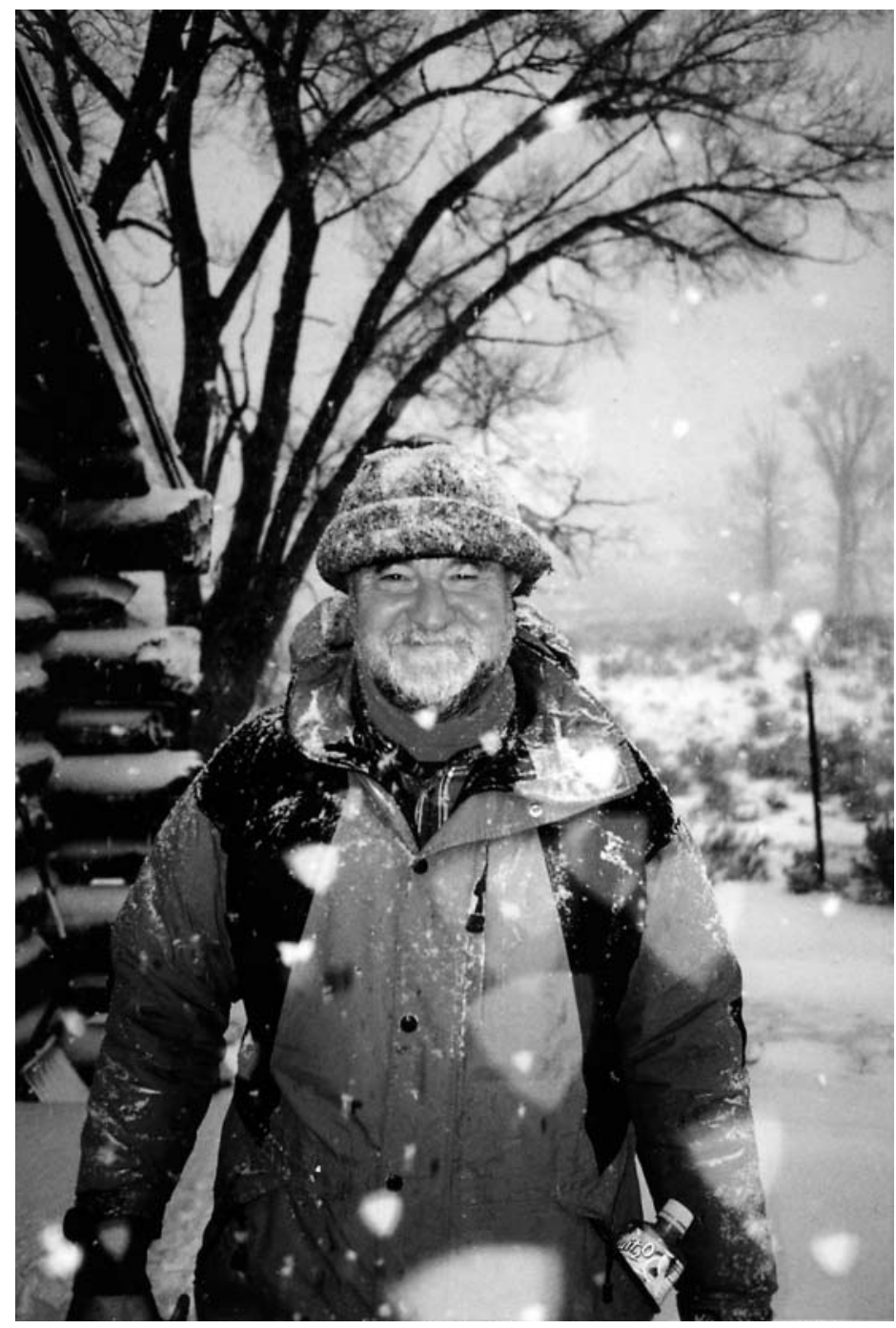

L. David Mech (www.davemech.org) is a senior research scientist with Northern Prairie Wildlife Research Center, United States Geological Survey; an adjunct professor at the University of Minnesota; and vice chair of the International Wolf Center (www.wolf.org). He holds a B.S. from Cornell University, a Ph.D. degree and Honorary Doctorate from Purdue University, and the Aldo Leopold award from The Wildlife Society. He has studied wolves for 48 years and published numerous articles and books about them.

Associate Editor: White. 


\section{ERRATUM}

Mech, L. D. 2006. Prediction Failure of a Wolf Landscape Model. Wildlife Society Bulletin 34:874-877.

DOI: $10.2193 / 2007-068$

Figure 1 in this article was incorrectly labeled. The title in Mech (2006) was

Figure 1. Wolf-pack territories formed in Wisconsin, USA, 1997-2004 (Wydeven and Wiedenhoeft 2004).

The correct title should have been

Figure 1. Wolf territories known to be present in Wisconsin, USA, in winter 2003-2004 (Wydeven and Wiedenhoeft 2004).

The map includes some territories that have been present since the 1970s, and some of the territories that appeared since 1997 had disappeared by winter 2003-2004. The full report where the figure originated is available at $<$ http://dnr.wi.gov/org/ land/er/publications/reports/WERR\%20Timber\%20Wolf/ WERR_Status_of_Timber_Wolf_03-04.htm >.

WSB apologizes to the authors for this error. 